\title{
Interaction of the human-rights ombudsman in the Russian Federation with human rights law enforcement (on the example of the prosecutor's office and the investigative committee)
}

\author{
Elizaveta Petrovna Demina ${ }^{1}$ and Nikita Vladimirovich Babich
}

RUDN University, Department of the Judiciary, Law Enforcement and Human Rights, Moscow, Russia

\begin{abstract}
The purpose of the study is to analyze some systemic problems in the organization and activities of the institution of the Human-Rights Ombudsman in Russia, bodies of the Prosecutor's Office, the Investigative Committee of Russia, as well as the conditions of interaction between the Human-Rights Ombudsman and law enforcement and human rights bodies. The methodological basis of the study was the use of system-structural and dialectical methods of scientific knowledge. For a more detailed study of the problems, the methods of analysis, synthesis, and generalization were applied. For the study of normative legal regulations, special methods of document analysis in the field of knowledge under study were applied. The result of the study was the conclusion that the protection of human and civil rights and freedoms is an integral part of a developed democratic state governed by the rule of law. The authors believe that in order to improve the quality of protection of human and civil rights and freedoms it is necessary, first, to reform a large number of elements of the state system. Particular attention in all this must be paid, first and foremost, to the organization, activities, and legal status of the institution of the Human-Rights Ombudsman in Russia, as well as the bodies of the Russian Prosecutor's Office and the Russian Investigative Committee. The second stage should be the creation of optimal conditions for interaction between the Russian Human-Rights Ombudsman and the Russian Prosecutor's Office, the Russian Investigative Committee, and other law enforcement agencies in order to protect human and civil rights and freedoms. The novelty of the study is in the author's approach to the consideration of these problems, as well as in the development of appropriate proposals to address them.
\end{abstract}

Keywords: Human-Rights Ombudsman, rights and freedoms, Prosecutor's Office, Investigative Committee

\section{Introduction}

${ }^{1}$ Corresponding author: $\underline{\text { demina-ep@,rudn.ru }}$ 
Democratic innovations that are present in the Russian state, as well as the formation of civil society and the creation of a legal and social state, require appropriate reform of the political, economic, social spheres, as well as the law enforcement system of the modern Russian state. One of the most difficult tasks of this transformation is to change and create the proper conditions for the relationship between the state and the individual. There is a clear legal gap between state authorities and citizens in terms of a gap between the law enforcement system and citizens, a fairly high level of malfeasance, unprofessionalism, nihilism in the field of law, lack of basic traditions in the protection of human and civil rights. All of this predetermines the necessity: of first, the emergence of new human rights institutions, second, bringing the existing mechanisms of interaction between society and state authorities into due condition, and third, bringing the law enforcement system of Russia into due condition.

At present, there is a fairly wide list of problems in the organization of the activities of the institution of the Human-Rights Ombudsman in the Russian Federation, the Prosecutor's Office, and the Investigative Committee. Problems, among other things, manifest themselves in the lack of proper conditions for general interaction between the Russian Human-Rights Ombudsman and these law enforcement agencies.

The following particular problems will be considered in this study:

1. Problems of constitutional legal regulation.

2. Problems of interaction between human rights institutions and law enforcement agencies.

3. The problem of the lack of the right of legislative initiative of the Ombudsman.

4. The problem of the advisory nature of the ombudsman's activities.

5. The problem of a disordered system for making appointments.

6. The problem of staff turnover.

Such problems result in significant violations of constitutional rights and freedoms of man and citizen, subject to violations of the authority of the developed state on the world stage.

These problems shall be eliminated in order to further the realization of human and civil rights and freedoms.

It is important to emphasize that a particular problem is in the interaction between the prosecutor's offices and the Russian Human-Rights Ombudsman.

\section{$2 \quad$ Methods}

Among the general scientific methods were used system-structural, dialectical method. For a more detailed study of the problems - analysis, synthesis and generalization.

For the study of normative legal regulations, special methods of document analysis in the field of knowledge under study were applied.

\section{$3 \quad$ Results}

The results of the study were developed by the authors of proposals for the modernization of Russian legislation.

First, it is necessary to provide in the provisions of the Russian Constitution a separate chapter on the Human-Rights Ombudsman, which would disclose, in full, his/her legal status in Russia.

Secondly, it is necessary to provide in the provisions of the Constitution of the Russian Federation a separate chapter on the Prosecutor's Office. To bring the status of the Law "On 
Prosecutor's Office" in accordance with the rules of legal technique, and to change the status from federal law to federal constitutional law.

Third, it is necessary to create conditions for productive work between the Russian Human-Rights Ombudsman and law enforcement and human rights bodies.

Fourth, the institution of the Russian Human-Rights Ombudsman does not compete with these bodies and does not pretend to take their place, but rather actively cooperates with them to ensure a decent level of protection of citizens' rights.

Fifth, the functioning of human-rights ombudsmen in the constituent entity of the Russian Federation revealed a number of legal problems, which the legislator is currently trying to eliminate. It seems that the adoption of the law on regional ombudsmen will be a positive moment in the development of this institution.

Sixth, short- and long-term programs shall be developed. The essence of the short-term is to expand the staff of the Office of the Ombudsman. The essence of long-term is to solve problems by either making changes or drafting laws.

Seventh, in order to reduce the accusatory bias in the activities of the prosecutor's office and to establish a closer legal relationship with the Russian Human-Rights Ombudsman, the function of public prosecution should be transferred to the investigators of the preliminary investigation bodies.

In order to compensate the prosecutor should be given such powers as the authorization of police and operational search measures to restrict the constitutional rights and freedoms of man and citizen; consideration of the petition on issues related to the election of preventive measures, etc. The prosecutor should become a kind of arbitrator at the pre-trial stage between the participants in the criminal process [1, p. 93].

Eighth, the concentration of investigative and supervisory authority in the prosecutor's office is unacceptable for objective reasons. This will not create the conditions for interaction with the Human-Rights Ombudsman.

Ninth, the Russian Ombudsman should pay due attention to the protection of the rights of medical workers, due to their apparent violation by the Investigative Committee of the Russian Federation.

Tenth, forensic units in the Investigative Committee of Russia should be abolished and a separate specialized service should be eliminated, like in the Republic of Belarus.

\section{Discussion}

Problems of constitutional legal regulation. The human rights activities of the Ombudsman in Russia contribute to: the resolution of many problems such as the contradictions of power and society; the legality of power, the observance, and implementation of rights and freedoms, etc. The idea of this institution will increasingly develop in the world [1, p. 93].

In February 1997, the Federal Constitutional Law "On the Human-Rights Ombudsman in the Russian Federation" was considered and subsequently approved. Then, in 1998, the first person was appointed to the position of Ombudsman in the Russian Federation. The following positions of specialized Ombudsmans were established at the federal level: the Presidential Ombudsman for the Rights of the Child (since 2009), the Presidential Ombudsman for the Protection of Entrepreneurs' Rights (since 2013), the Ombudsman for the Rights of Consumers of Financial Services (since 2018). Positions of Ombudsman for the Rights of the Child and for the Protection of Entrepreneurs' Rights were also established at the level of constituent entities of the Russian Federation [2. p. 49]. 
The institution of the Human-Rights Ombudsman is not adequately regulated within the Russian Constitution, while it is provided for other institutions and bodies of state power. It is this constitutional problem that has been pointed out by Russian and foreign legal scholars. This raises a reasonable question - why is there no separate chapter in the Russian Constitution devoted to "The Bar and the Ombudsman in the Russian Federation", similar in structure and name to Chapter 7 "The Judiciary and the Prosecutor's Office"? The Russian Federation is a state governed by the rule of law and democracy with various institutions that protect human and civil rights and freedoms on an equal footing with the judiciary and the prosecutorial authorities.

Moreover, every legal scholar understands that the system of checks and balances in the modern world needs human rights institutions, as opposed to law enforcement agencies. If there are none, or their legal status is not clearly defined as in Russia, it leads to a strong accusatory bias not only by law enforcement agencies but also by the judiciary, as is now observed in Russia. Based on this, a group of such provisions should be developed and introduced into the Russian Constitution.

In this regard, we believe that the formation of chapters of the Russian Constitution, which cover two institutions or bodies of state power, each of which has its own characteristics of organization and activity cannot be considered permissible.

So, the retention of Article 129 in Chapter 7 "The Judiciary and the Prosecutor's Office" of the Basic Law, devoted to the prosecutor's office, does not correspond to the legal organization of the system of state power. In accordance with current legislation, the judiciary and the prosecution service are two bodies of state power, which have completely different functions and purposes. In its legal position within Russia's law enforcement system, the prosecutor's office is independent of the court. It seems that this legal problem can be solved in two ways. The first approach is more extensive in terms of reformation. Its essence is to change the legal position of prosecution bodies in the system of state authorities by organizing prosecution bodies under the Supreme Court of Russia and lower courts. Such a reform would ultimately justify the existing combination of the court and the prosecutor's office in one chapter. However, Article 129 with its amendments (criminal prosecution) would contradict the concept of separation of powers and create conditions for a more accusatory bias of the court and prosecutor's office; reduction of the independence and impartiality of the court, etc.

The essence of the second approach is to develop and create a separate chapter devoted to the Prosecutor's Office of Russia. The main thing in this approach is that the court should de jure and de facto exercise only the function of administration of justice.

As a result of this approach in practice, the legal problem will be eliminated; the authority of the judiciary and prosecutorial authorities will increase; the basic law will be brought into a legally competent document, and will meet the international standards of a developed state governed by the rule of law.

With regard to the above, it is necessary to develop and form separate chapters on the Ombudsman in Russia and the Bar on the same principle. The recommended titles of these chapters are: 1) the chapter "Human-Rights Ombudsman" and 2) the chapter "Advocacy and the Legal Profession".

Problems of interaction between human rights institutions and law enforcement agencies. One of the serious problems in this area is the interaction of the Russian Human-Rights Ombudsman with the prosecutor's office.

The Human-Rights Ombudsman, as an institution of human rights activities, can contribute to the achievement of the goals and objectives of prosecutorial oversight in criminal proceedings. Only with prosecutorial bodies, based on the theory of prosecutorial 
and human rights activities, there can be such interaction. It is worth mentioning that such interaction is permanent or temporary and stops when the tasks are resolved. It manifests itself in two forms: 1) transmitted materials, information, documents, which will be necessary in the consideration of complaints, and which will allow to confirm or refute the arguments written in the appeals; 2) general exchange of information [3, p. 60].

In the current model of the organization of the prosecutor's office, such legal relations are in general difficult. There is a strong accusatory bias in the activities of prosecutorial authorities, which leads to violations of human rights and freedoms. And the key goal of the prosecutor is not to find the objective truth but to achieve a conviction in court. Under such circumstances, any positive communication with the Russian Human-Rights Ombudsman is virtually impossible. Although it is the prosecutor's office that is the guarantor of the rule of law.

It will not contribute to the development of positive legal relations if the prosecutor's office is returned to the investigative and supervisory functions under the pretext of strengthening the mechanism of prosecutorial oversight. Giving such functions to prosecution bodies will lead us to the problems we had before 2007 and before 2011 [4, p. 60]. Once again there will be one official in criminal proceedings, who will simultaneously implement the independent initiation of criminal proceedings, the investigation, control and supervision of itself, and support of prosecution in court. In addition to this, the investigator will be completely dependent on the prosecutor's instructions, which will lead to a complete loss of the already questionable procedural independence of the investigator.

The concentration of investigative and supervisory powers in the hands of the prosecutor alone would create, first, a very high risk of increased official powers and violations of human and civil rights and freedoms in criminal proceedings, and, second, the fairness of court decisions would not improve for objective reasons [5, pp. 760-769].

In order to create the conditions for interaction between them, it is necessary to completely reform not only the institution of the Ombudsman in the Russian Federation but also the prosecutor's office itself.

First, it is necessary to reconsider the basis of the activities of prosecution bodies and to include in the Constitution of the Russian Federation and other federal legislation as an obligatory principle the establishment of objective truth at all stages of criminal proceedings. The prosecutor shall learn to drop the charge if he/she finds that the person is not guilty. The prosecutor should not be disciplined; on the contrary, he/she should be encouraged, because he/she has established the objective truth and fulfilled the main task entrusted to him/her by the people of the country.

Second, the legal position of the prosecutor should be reconsidered from the accuser to a kind of independent pre-trial arbitrator between the investigator and institutions whose functions are related to human rights work. It is not necessary to give the prosecutor the right to bring criminal cases and investigate them, there are other powers. The function of the investigation should be transferred to the Investigative Committee of Russia. Perhaps even the function of public prosecution should be transfered to the investigator. In order to increase the role of the prosecutor's office in criminal proceedings, the rule of law, and to reduce accusatory bias, the powers of the judge, which are not inherent to the prosecutor, should be transferred to the prosecutor. Such powers, for example, include authorization of police and operational search activities to restrict the constitutional rights and freedoms of man and citizen; consideration of applications on issues related to the election of preventive measures; consideration of complaints related to the issue of inadmissibility of certain evidence; and a number of others [1]. And the court should only be concerned with the administration of justice. 
The revision of such a legal position of the prosecutor will allow solving several significant problems, namely reducing the level of contradictions between the prosecutor's office and the Investigative Committee of Russia, increasing the objectivity and responsibility of the court, prosecutor's office, and investigator and finally creating and establishing conditions for the relationship between prosecutors and the Ombudsman in Russia in order to properly ensure and protect the rights of citizens.

The next law enforcement agency with which there is a clear problem of relations with the institution of the Human-Rights Ombudsman is the Investigative Committee of Russia.

In order to build a state based on the rule of law in Russia, it is necessary to achieve at least the slightest degree of interaction between the Investigative Committee of Russia and the Human-Rights Ombudsman.

At first glance, this interaction does not seem real. However, the essence of the creation and activities of the Investigative Committee of Russia, laid down in the judicial concept of 1991, proves the contrary. The main principles of procedural activity of investigators should be the establishment of objective truth and the investigation of crimes that took place in reality, and no fulfillment of the plan of detectability (the principle of "no crime - no investigation"). General interaction between the Investigative Committee and the Ombudsman can manifest itself in the federal search for a criminal, restoration of rights and compensation to the victim, the identification of unscrupulous investigators, i.e. assistance to investigators of control and investigative units and heads of investigative units, etc.

Unfortunately, with the current organization and activities of both the Investigative Committee of Russia and the Ombudsman in Russia, such legal relations are impossible, since the first body is a punitive, accusatory one, while the second is a human rights institution. Each of them has its own goals and objectives.

Today, the Russian Human-Rights Ombudsman can help to curb the punitive and prosecutorial activities of the Investigative Committee of Russia.

Such assistance of the Human-Rights Ombudsman is particularly acute in ensuring the rights and freedoms of medical workers in the investigation of crimes. The leadership of the Investigative Committee organized a large-scale campaign against doctors.

To investigate crimes in the medical sphere, the Investigative Committee established its own units for the investigation of iatrogenic crimes and forensic medical examinations. The creation of units for the investigation of iatrogenic crimes can be considered a positive element of the system, although the model of their organization remains wanting. There should be set up not small offices in the Central Office, but an entire department with divisions.

As for the departmental expertise, especially in terms of the actions of the doctor, this is a big disadvantage and the collapse of the entire system of objectivity of the investigation. Undoubtedly, common departmental practical interests and accountability plans will manifest themselves here. In such an organization, the expert will always be administratively subordinated to the management and the investigator. And it is well known that any expert activity shall be independent of the investigative one. Otherwise, the objectivity of such decisions will always be in doubt. This is also the opinion of human rights activists [6].

We believe that it would be more correct to create a specialized service for forensic medical examinations independent of the Investigative Committee and the Russian Ministry of Health.

This approach will provide conditions for increasing the objective assessment of the physician's actions. Accordingly, there will be an interaction between the Investigative Committee of Russia and the Human-Rights Ombudsman, where the former and the latter 
will be interested in protecting and respecting the rights of both the medical worker and the victim. But until such a reform of the system occurs, explicit participation and public control by the Ombudsman in Russia is required solely for the purpose of respecting the rights of the medical worker. The scant range of powers of the Ombudsman in the Russian Federation does not contribute to the independent resolution of this task. In this case, clear joint participation of the prosecutor's office is necessary.

The problem of the lack of the right of legislative initiative of the Ombudsman. The Ombudsman is entrusted with the great responsibility of protecting and restoring human rights and freedoms. However, according to Article 10 of the Law of St. Petersburg "On the Human-Rights Ombudsman in St. Petersburg" adopted on December 17, 1997, the Ombudsman is entitled to submit relevant proposals to the subjects of legislative initiative, which significantly complicates his/her activities and reduces the effectiveness of the Ombudsman's office as a whole. It needs to be empowered to participate in the legislative process. For this purpose, it is necessary to make amendments to the law "On the Human-Rights Ombudsman" No. 227-77 dated December 30, 1997, which concern giving the Ombudsman the right to legislative initiative, as well as to amend Article 31 of Chapter 5 of the Charter - to include the Ombudsman in Russia among the holders of the right of legislative initiative.

The problem of the independence of the ombudsman. According to the second paragraph of Article 1 of the current law on the Ombudsman, the Ombudsman is independent of state authorities and officials in the exercise of the powers vested in him/her. Since it is not specified here, that is, it does not say what exactly is meant by independence, it can be interpreted in different ways. In a narrow sense, this paragraph can be understood as the isolation of the Ombudsman's office from the legislative, executive, and judicial branches of power, freedom from pressure from the authorities, that his/her powers are not terminated when the term of the Legislative Assembly expires, immunity, which is manifested in a special procedure for an administrative and criminal prosecution, as well as the inviolability of his/her living and official premises, correspondence, baggage, vehicles, communication facilities, documents. If we consider the concept in a broader sense, then there are just the same inconsistencies. For example, according to Article 4 of the above-mentioned law, the Legislative Assembly as well as other state bodies play a major role in the nomination and dismissal of a candidate for the position of Ombudsman. The previous section provided a more detailed consideration of the contradictions of this independence of the Ombudsman, so in order to avoid repeating, there shall be considered the methods of implementing the previously proposed solutions to the problem. So, it is necessary: [3, p. 25].

to amend the law on the Ombudsman, namely to specify paragraph 2 of Article 1, that is, to describe in more detail what is meant by the independence of the Ombudsman;

to limit the power of the Legislative Assembly and other state bodies over the institution of the Ombudsman, amend at the same law Article 4 to introduce a new person - the Human-Rights Ombudsman in the Russian Federation - in addition to the mentioned persons with the right to make proposals for a candidate;

in clause 1 of article 5, the ombudsman is elected and dismissed by the Legislative Assembly, which limits his/her independence, since it is on the other side of the barricade, so it is necessary to transfer this power (to elect and dismiss the ombudsman) to the Human-Rights Ombudsman in the Russian Federation.

The problem of the advisory nature of the ombudsman's activities. The following acute problem is the recommendatory nature of the Ombudsman's activities, that is, there is no punishment for non-compliance with these recommendations, so there is an increasing 
disregard of the Ombudsman's recommendations by government agencies. In order to ensure that the work of the Ombudsman was not in vain, but contributed to the improvement of the human rights atmosphere, it is necessary to amend the law "On Human-Rights Ombudsman" by adding paragraphs "Deadlines for consideration of recommendations of the Ombudsman by state agencies" and "Liability for non-compliance by state bodies and officials with recommendations of the Ombudsman". It shall be specified within what time period, after receiving recommendations from the Ombudsman, the state body shall consider them and give the necessary reaction, and in case of its absence or violation of the terms of consideration to bear the appropriate responsibility in the form of, for example, a fine. The obligation to respond will increase the degree of interaction between government agencies and the Ombudsman in Russia. His/her activities will cease to be unidirectional and unresponsive [7, p. 17].

The problem of the lack of preventive orientation in the activities of the Ombudsman. In order for the activities of the Ombudsman to be not only reactive (reaction to a violation of rights that has occurred), but also preventive (implementation of measures to prevent violations of rights), it is necessary to amend Article 13 of the Law on the Ombudsman, namely to provide him/her with the right to act on his/her own initiative in cases where it is necessary to prevent violations of the rights and freedoms of citizens, as in Sweden, Poland, Spain, the Czech Republic, and many other countries. In this case, this is about preventive inspections, for example in places of detention, educational institutions, nursing homes, and other institutions, as well as, for example, the action of the Ombudsman after receiving information from the media or other sources, without waiting for an appeal with rights violations [8].

The problem of a disordered system for making appointments. The next problem is the disordered system of citizens' registration. Because it is not uncommon for citizens to make an appointment and not show up unannounced, time is wasted. As has already been mentioned that it is necessary to implement a system to remind citizens about appointments by calling, sending a message to the phone, or sending an e-mail. This reminder system should be applied the day before the reception of citizens by the Ombudsman's Counselor. At this point, it is the only true and most effective solution [9, p. 73].

The problem of staff turnover. Employee turnover is an important indicator of the internal organization of employees. It is believed that there should be:

1) Revised the wage system. For this purpose, it is necessary to introduce amendments about the increase of the amount of the official salary of the positions of the Ombudsman's office in Article 7 of the law "On the Register of public positions of St. Petersburg and the Register of civil service posts of St. Petersburg" No. 302-34 dated June $8,2005$.

2) Increase the number of employees in the office, which helps to reduce the workload, and possibly get rid of the first point, associated with an increase in the amount of the salary. The number of staff can be increased from 33 to 40 people. It is also important to allocate a more spacious room.

3) At least once a month, an anonymous survey should be conducted among the staff, with questions about the leaders, about the organizational atmosphere, and about suggestions that would increase the potential of the staff. This survey shall be conducted electronically. The survey should include both open-ended and closed-ended questions.

These proposals should open a whole new "door" to the Ombudsman and his/her office.

\section{Conclusion}


The results obtained in the course of the study, implemented in the proposed amendments to the Russian legislation will provide conditions for increasing the objective assessment of the actions of the Human-Rights Ombudsman. Accordingly, there will be an interaction between the Investigative Committee of Russia and the Human-Rights Ombudsman, where the former and the latter will be interested in protecting and respecting the rights of both the suspect and the victim.

\section{References}

1. V.A. Chukreev, Russian Juridical Journal, 5, 93-99 (2018)

2. V.A. Ignatenko, Actual problems of jurisprudence, in Collection of articles on materials of XXVI international scientific-practical conference, 9(25), 49-56 (LLC SibAK Publishing House, Novosibirsk, 2019)

3. D.G. Kelmakova, Mariysky Juridichesky Vestnik, 2(21), 60-61 (2017)

4. A.M. Bagmet, Yu. Tsvetkov, Lex Russica, 4, 60-70 (2015)

5. N.V. Babich, Vestnik PFUR. Series: Legal Sciences, 3, 760-769 (2020)

6. E. Borzenkova, Ekspertiza ot SKR: chto pomenyaet novyi proekt Putina o starykh initsiativakh Bastrykina [Expertise from the Investigative Committee of Russia: What Will Change Putin's New Project About Bastrykin's Old Initiatives]. Accessed on: July14, 2020. [Online]. Available: https://pravo.ru/story/209812/

7. B.V. Larin, Actual Problems of Combating Crimes and Other Offenses, 16-1, 10 (2018)

8. Models of the ombudsman institution in federal states. Accessed on: February15, 2021. [Online]. Available: http://revolution.aUbest.ru/law/00670522_1.html

9. V. Serzhanova, Vestnik VSU. Ser.: Right, 2, 33-43 (2010) 